\title{
The Multidimensional Perspective and Impact of Media-Induced Tourism over Indian Tourism Sector
}

\author{
Sriganeshvarun N, Jayaprakash D
}

\begin{abstract}
Indian tourism sector is one of the world's leading excursion zone. As per the India Brand Equity Foundation [IBEF]. India has 30 world heritage sites to showcase its rich tourism diversity. In 2018, The Foreign Tourism Arrivals [FTA] was recorded approx. 10.6 crores which are a whopping 5\% escalation from the previous year. Indian movies are way popular throughout the world. Several Oscar-winning movies were shot in India. Some of them are Life of Pi (2012), Slumdog Millionaire (2008), Gandhi (1982) etc. With the popularities of these movies, scenes and location too got popular. The worldwide popularity of such movies escalates the tourism business catalytically. The escalation of tourism leads to improved tourism revenue, jobs, foreign exchange and occupation. The media-induced tourism is the key to the growth of a country's tourism income but sustainable planning is needed to encash tourism revenue. Even after receiving the tourist major concern are tourist safety, comfort, expenditure, visa process and a lot more. Our proposed paper is about the discussion over cinematographic tourism, the relation of film-induced tourism and measures taken over the upliftment of media-induced tourism.
\end{abstract}

Index Terms: India Brand Equity Foundation [IBEF], Foreign Tourism Arrivals [FTA]

\section{I.INTRODUCTION}

Ever since the world's first screening of a movie took place in Grand café of Paris in 1985 using a projector called cinematographe. It was basically a chain of videos of people's life in France and worker's going out of Lumiere Factory. The Lumiere factory became the first place in the history screened and it gave the factory location historic importance. This was the start of Film Induced tourism which brought a big impact over the tourism sector throughout the world. Film induced tourism is actually a cinema spot visit which gets marketed by the movies. It has a huge impact on the people mindset to make any tourist location popular overnight. There was a time when Ooty was not a popular tourist destination for North Indians but once 'Hathi Mere Sathi featured the then megastar Rajesh Khanna came in cinema, the crowd of people started to rush over the places of Ooty. The movie was shot in 1941 but still, after 48 years the magic sustains. If we visit Ooty the tourist guide surely tells the story of the movie locations. Several regions of the

Revised Manuscript Received on December 30, 2019.

Sriganeshvarun N , Ph.D. Research Scholar Department of Visual Communication, School of Mass Communication, Vels Institute of Science Technology and Advanced Studies (Deemed to be University), Chennai, India.

Dr. Jayaprakash D , Associate Professor \& Head at Department of Visual Communication, Meenakshi Academy of Higher Education and Research (Deemed to be University), Chennai, India. country are totally dependent on the tourism sector for their income.

Film Induced Tourism is a much-discussed topic today due to its efficiency and scope. There was a time when people used to think about the places like Shimla, Manali, Kashmir, Kodaikanal, Agra as the most important place of a tourist attraction but the situations are altered a lot today. The traditional places are mostly overcrowded and expenditure to visit such places are out of reach for middle-class travellers There was a strong need to make use of other tourist places which were unidentified by people all over the world. After the emerging of Film Induced Tourism, the situation becomes much better for the less popular tourist attractions. If we talk about Ladakh immediately the movies name like 3 Idiots and Zindagi Na Milegi Dobara reflects in our minds. Many such places of North Eastern part of the country like Manipur, Assam, Nagaland, Shillong, Mizoram were not so popular for tourism. Immediately after the movies like Rock On 2, Dansh, Saaya, Harpal, Daman etc., suddenly the places of shooting became famous and tourism-friendly.

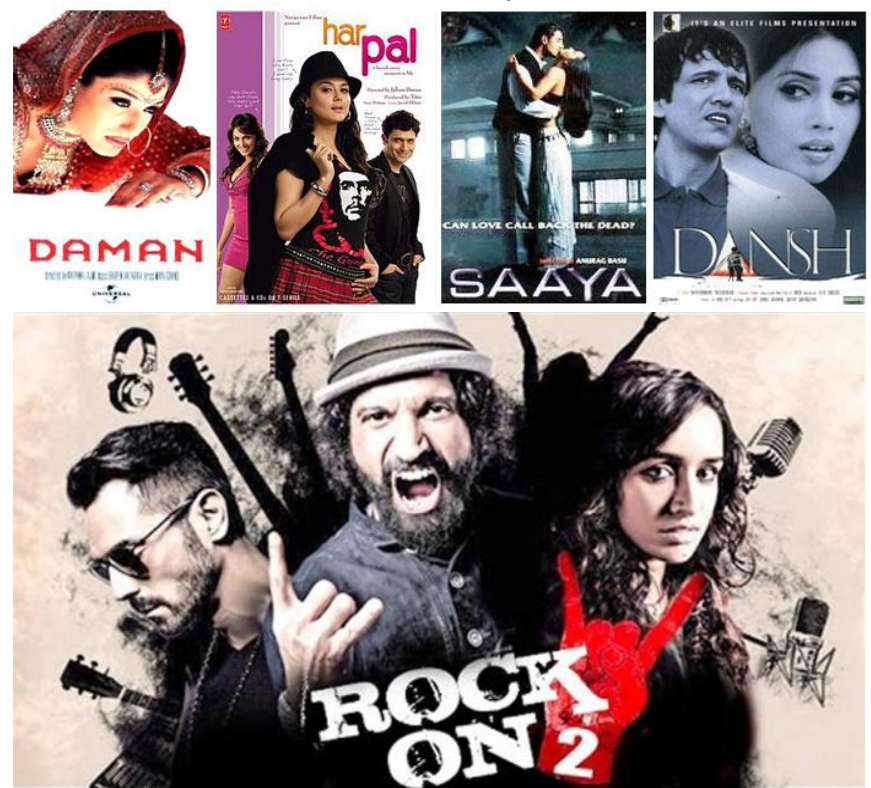

Fig. 1.1 - Movies which induced tourism in North-Eastern India

The cinema induced tourism provides a pathway to the rapid development of a place of tourist attraction almost instantaneously. Using proper planning and efficient ideology the cinema can act as the bridge between tourist and not so famous tourist places. Such an attempt is taken recently by the states like Tamil Nadu,

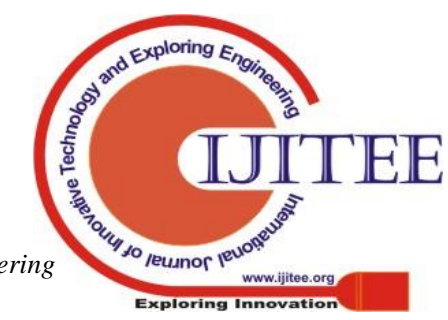


Uttar Pradesh and Kerala which has great scenic beauty and places of historic importance. In our next section of the paper, we discuss all the Literature Survey over the topic.

\section{LITERATURE SURVEY}

[1]. Ledid Bin Abdul Khader explained briefly in his paper about "Film Induced Tourism" in India. He highlighted the film's benefits to create new tourist places. The concept of existing tourist places is transformed as creating tourist places due to the concept of film-induced tourism. He further extended that, by reviewing the existing researches new research areas can be approached as new tourism destinations are often developed by the film industry.

He also explained to the capital aspect of tourism over the Indian economy and GDP. He also referenced some shooting locations which became famous due to movie shoot on the locations The suggestion were also provided to increase the income from film-induced tourism for Indian Government. The paper gave clear conceptualization of the film-induced tourism, its origin, impact and improvement possibility with current perspectives.

[2]. In a paper titled 'Indian Cinematic Tourism, 'it was statistically stated that the industry of cinematography has a gradual rise from 92.7 to 219.8 billion from 2007 to 2018 correspondingly. There is a huge chance of growth and development in film-induced tourism. Cinematic tourism was effectively categorized as one shooting and producing the movies, secondly tourist attraction toward the location as the result of the shooting.

The benefits of national and state government were extensively defined. They provided the complete locations of recent shoot movies on tourist places and even the places which were not of great tourism locations by Indians. The facts and figures about, how different country's government helped the film producers of Indian movies like Life of Pi, Zindagi Na Milegi Dobara by subsidizing and refunding the VAT, reducing the fee for hotel stays, easy VISA process and a lot more. This paper gave another clue that how films can be effectively promoted to increase the country's travel and tourism economy. There are several possibilities of boosting a tourist place in India itself if the State Government take necessary steps to help the film industry for film making in their tourist locations. Tax reduction, hotel concession, transportation discounts and security of film stars can easily enhance the film production in a State. This can increase the film making in a regional location and its business possibility.

[3]. Mijalce Gjorgievski and Sinolicka Mellas Trpkova briefly explained in his spaper "Movie Induced Tourism". A new tourism phenomenon about the tourism industry and its coherence with globalization. They also explained how people get inspired to relieve themselves on the movie locations in movie characters. The tourism induced by movies has the ability to boost up the tourism sector of the country. Particular locations can be publicized by the means of the movies.

He also discussed the push and pull factors in film-induced tourism. Pull represent the attraction of tourists for a location due to its scenic beauty. Weather, location serenity etc. where push represents the ones predisposing the travel like Romance, fantasy, curiosity and enthusiasm.

\section{SYSTEMATIC PLANNING AND ADVANTAGES}

There is a huge impact of Film-Induced tourism over a country's tourism sector. There is a strong need for systematic planning to further improve tourism by films.

\subsection{Systematic Planning for Enhanced Film Tourism Sector}

These are the proposed measures which can increase the Film- Induced tourism for sure.

1. The country should also invite foreign movie makers to shoot their movies in Indian locations. This can be a great impact on foreign tourists to visit India. Many such movies increased the tourism business before also.
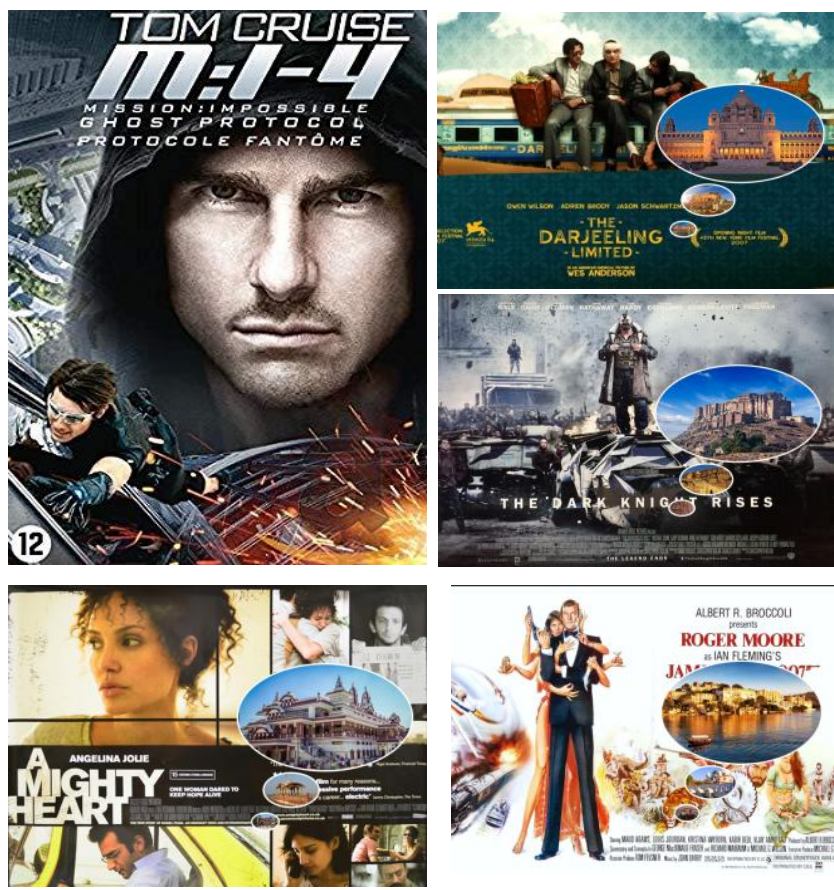

Fig. 3.1 - Hollywood Movies Shot in India

2. Every state should point the tourist locations which could be used for the film shootings and rank it as per the scenic beauty, historical connections, lesser sensitivity and possible crowd control.

3. State representatives should contact the film producers with the proposal of discounted fee and other advantages what they can avail for the film locations in their region.

4. Film cast should get security, smooth paper works and local guide to ease their shoot in the regional locations.

5. Local restrictions and belief should be informed to the concerned movie authorities to avoid conflicts with locals which took place during the shooting of movies like Padmaavat and Ham Saath Saath Hai.

6. After the movie shoot, the location of the shoot should be promoted for further movies and tourist attractions using print and digital media.

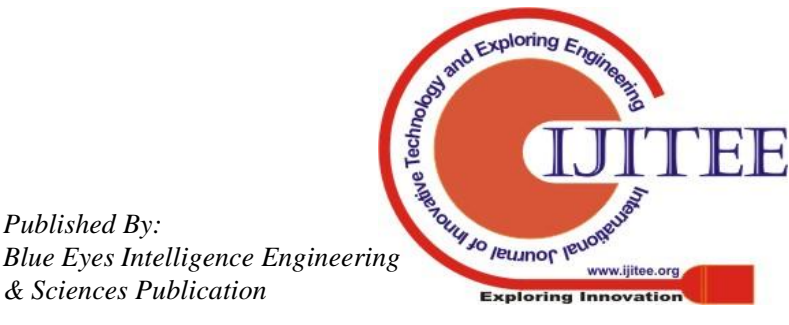


7. Film cast should be provided with the proper security to avoid the unpleasant cases faced by many movies cast like Mahi Gill was attacked by Goons during the shoot of "Dev D", the cast and crew members of a web-series titled Fixer, Sanjay Leela Bhansali during Padmaavat etc.

\subsection{Benefits of Film-Induced tourism over the public,} state and country

The Diagram below represents how the State and National policies of government can utilize the advantages of Film-Induced tourism for the countrymen. How the Public, State, Country gets benefited by utilizing the steps to further boost its tourism by means of films.

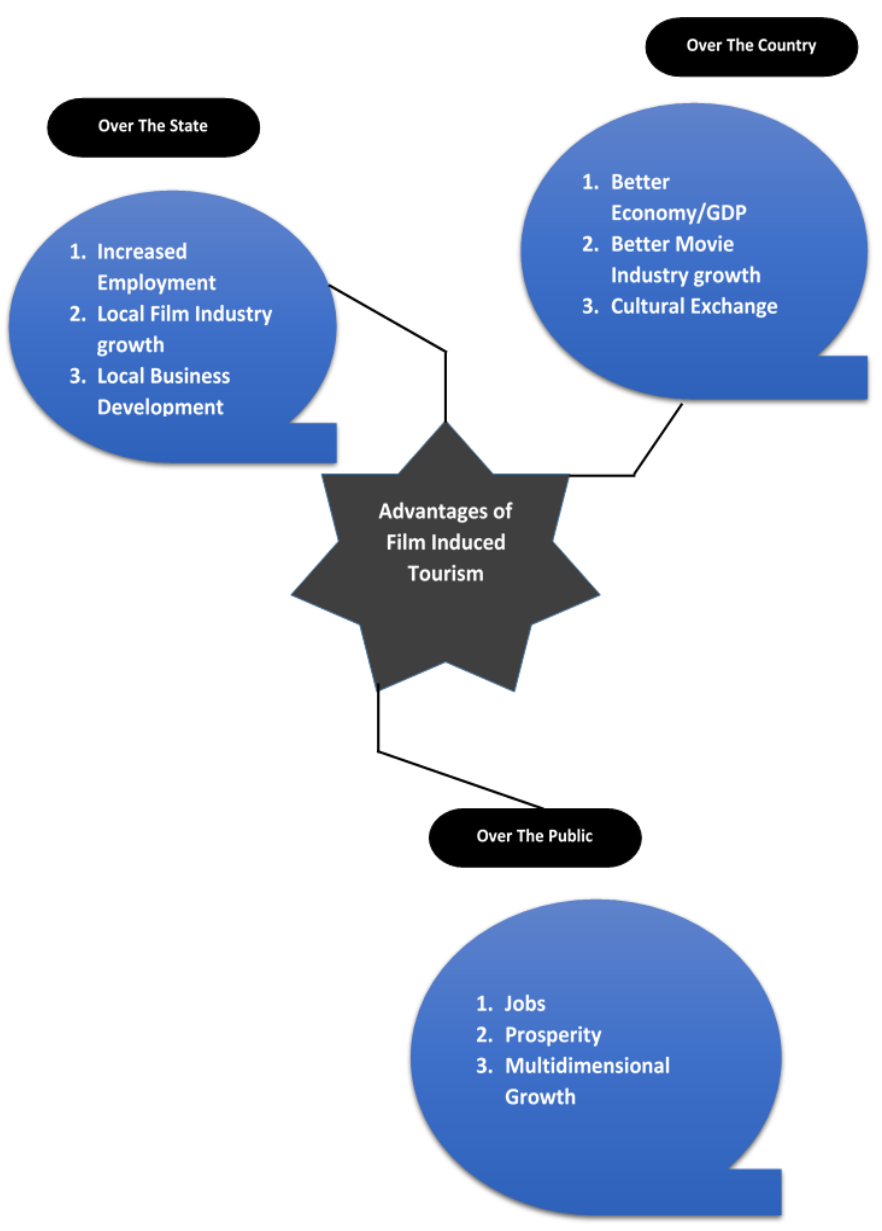

Fig. 3.2 - Advantages of Film-Induced Tourism

\section{DANGERS INVOLVED IN FILM-INDUCED TOURISM AND SURVEY \& RESULTS}

There are several factors which affect the film-induced tourism in different ways.

When the viewers watch a movie for 2-3 hours they actually enter the virtual world leaving aside their worries and daily routine conflicts. Till the movie plays, the viewers relate and imagine themselves in the movie with the characters. The connection becomes much eminent when the movie locations are beautiful, pleasant, thrilling and romantic. In many ways, the locations trigger the zeal of tourism and particularly to the same spot of the movie got shot. Many times the scene escalates the tourism sector with such efforts to make the place much popular.
There are several movie locations which were too dangerous to visit just to see the scenic beauty. These places should be avoided and they are discussed below which can severely affect the movie induced tourism.

\subsection{Dangerous shooting locations and suggestions for tourist safety}

Some of the shooting locations are very easy to reach of tourism in terms of geographical locations, money matter, safety concerns, family perspective etc. Some locations are geographically difficult to reach by common people.

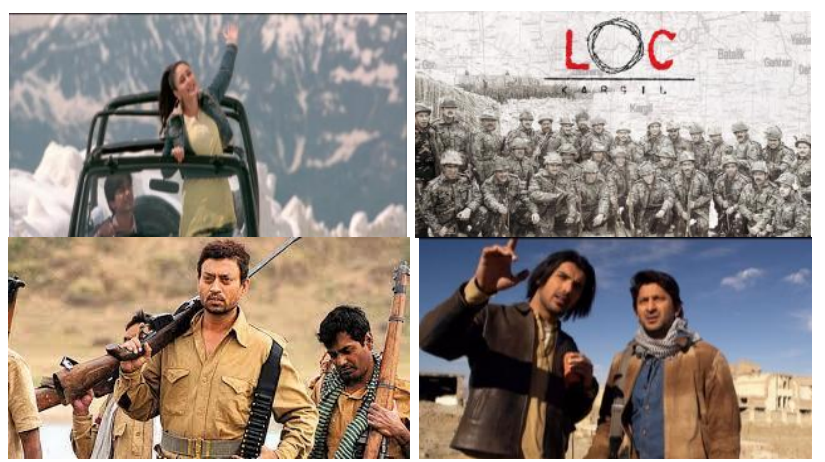

Fig. 3.2 - Movies Shot in the most dangerous locations

- Loc Kargil was a war magnum opus which was shot on Ladakh. It had an altitude 3000 meters and temperature of -20 to -10 during the shoot. 2 crew members died during the movie shoot. Travellers should be extra careful to select proper season to visit such locations when the temperature is bearable.

- During the shoot of Kabul Express in Afghanistan actors, Arshad Warsi and John Abraham received several calls by the local terrorist groups to quit off the shoot. Their life was at stake during the shoot. Tourist should avoid the locations of terrorism sensitively.

- Jab We Met movie song 'Yeh Ishq Haye' was shoot in Rohtang pass which was extremely cold and at the altitude of almost 4000 meters above sea level. Vehicles met several accidents as the tyre skid over the icy roads.

- Paan Singh Tomar movie was actually shot at the ravines of Chambal. Having real dacoits in the location it was really dangerous to shoot even the shortage of amenities was a problem there.

\subsection{Survey and Resultant}

A survey about tourist places with film connection over 5 tourists recently visited Munnar, Ooty, Jammu \& Kashmir, Shillong and Darjeeling. We surveyed them to identify whether they knew that the movies were shot on their visiting place, expenditure to stay, overall experience score and any special feedback.

The questions were as follows.

1. What was your visiting location?

2. What are the names of the movie which were shot on your tourism location?

3. What was the expenditure per person to visit for 3 days?

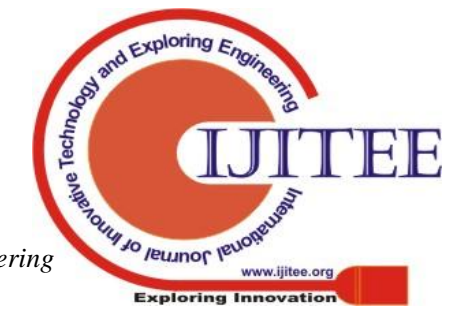


4. How was the overall experience score based on expenditure, transportation, flooding, language and enjoyment? [Scale of 1 to 10]

5. Do you have any feedback about the place?

Answer what we got are as follows.

\begin{tabular}{|c|c|}
\hline \multicolumn{2}{|c|}{ Tourist 1 } \\
\hline Ans. 1 & Munnar (Kerala) \\
\hline Ans. 2 & Chennai express and Life of Pi \\
\hline Ans. 3 & INR 20,000 \\
\hline Ans. 4 & 9 \\
\hline Ans. 5 & A must visit Place \\
\hline
\end{tabular}

Table 1:- Survey Answers for visitor 1

\section{Tourist 2}

\begin{tabular}{|c|c|}
\hline \multicolumn{2}{|c|}{ Tourist 2 } \\
\hline Ans. 1 & Ooty (Tamil Nadu ) \\
\hline Ans. 2 & $\begin{array}{c}\text { DIL se, Sajan, Barfi, Kuch Kuch Hota Hai, Ajab } \\
\text { Prem Ki Gazab }\end{array}$ \\
\hline Ans. 3 & INR 15,000 \\
\hline Ans. 4 & 7 \\
\hline Ans. 5 & $\begin{array}{r}\text { A good place to visit considering the appropriate } \\
\text { season, avoid the rainy season }\end{array}$ \\
\hline
\end{tabular}

Table 2:- Survey Answers for visitor 2 Tourist 3

\begin{tabular}{|c|c|}
\hline \multicolumn{2}{|c|}{ Tourist 3 } \\
\hline Ans. 1 & Jammu \& Kashmir \\
\hline Ans. 2 & AAP Ki Kasam, Bobby, 3idiots, Highway, Haidar \\
\hline Ans. 3 & INR 25,000 \\
\hline Ans. 4 & 6 \\
\hline Ans. 5 & $\begin{array}{c}\text { A great place but extreme climate and unstable } \\
\text { situations sometimes make the visit complex }\end{array}$ \\
\hline
\end{tabular}

Table 3:- Survey Answers for visitor 3

\begin{tabular}{|c|c|}
\hline \multicolumn{2}{|c|}{ Tourist 4 } \\
\hline Ans. 1 & Shillong (Meghalaya) \\
\hline Ans. 2 & Kurbaan and Rock On 2 \\
\hline Ans. 3 & INR 17,000 \\
\hline Ans. 4 & 7 \\
\hline Ans. 5 & A superb place to visit \\
\hline
\end{tabular}

Table 4:- Survey Answers for visitor 4

\begin{tabular}{|c|c|}
\hline \multicolumn{2}{|c|}{ Tourist 5 } \\
\hline Ans. 1 & Darjeeling (West Bengal) \\
\hline Ans. 2 & Barfi, Parineeta \\
\hline Ans. 3 & INR 15,000 \\
\hline Ans. 4 & 8 \\
\hline Ans. 5 & A great place for family holidays. \\
\hline
\end{tabular}

Table 5:- Survey Answers for visitor 5

\section{CONCLUSION}

Thus we researched over almost every perspective of Cinema- Induced Tourism. The detail about film-induced tourism, its advantages over the tourism sector, chance of growth and the initiatives to enhance the film-induced tourism is discussed in detail. We worked over the survey of several foreign movies shot in different Indian locations which hugely contributed towards international tourism and local revenue growth. We also went through the people awareness about dangerous places of shooting importance which should be mostly taken care of. A survey was also conducted over five visitors group for five different tourism locations of cinema background. We concluded that people often want to visit stable locations irrespective of expense but movie is always a medium to escalate the visitors. In future, we will discuss different states of India which contribute differently in the film-induced tourism and what measures the south film industry took to make their state shooting location a tourist magnet.

\section{REFERENCE}

1. Riley, R. W., \&Van Doren, C. S. (1992).Movies as tourism promotion, a pull factor in a push location. Tourism Management,13(3), 267-274. doi: 10.1016/0261-5177(92)90098-R.

2. Riley, R.W., Baker, D., \& Van Doren, C.S. (1998). Movie induced tourism. Annals of Tourism Research, 25(4), 919-935. doi/10.1016/S0160-7383(98)00045-0.

3. Roesch, S. (2009).The experiences of film location tourists. (1sted.) Bristol, UK: Channel View Publications.

4. Ryan, S. (2012). Bollywood film shot in dublin expected to be watched by 100 million people. The Journal.ie, Retrieved from http://www.thejournal.ie/

bollywood-film-shot-in-dublin-expected-to-be-watched-by-100-millio n-people-557882-Aug2012/.

5. Sellgren, E. (2011).Film-induced tourism: The effect films have on destination image formation, motivation and travel behaviour. Saarbrücken, Germany: Lambert Academic Publishing.

6. Smith, A. (2005). Conceptualizing city image change: The „re-imagingee of barcelona.Tourism Geographies,7(4), 398-423. doi $10.1080 / 14616680500291188$

7. Spain wants Indian tourists, filmmakers. (2011, September 25).eTurboNews Group. Retrieved from http://www.eturbonews.com/25411/spain-wants-indian-tourists-film makers.

8. Tagliabue, J. (2012, Oct 20). Yash Chopra's love affair with Switzerland.The New York Times. Retrieved from http://movies.ndtv.com/

bollywood/yash-chopra-s-love-affair-with-switzerland-282805

9. TNN (2006, Jun 26).Singapore gears up to encashKrrish. The Economic Times. Retrieved from http://articles.economictimes.indiatimes.com/2006-06-26/news/.2742 6133_1_singapore-tourism-board-assistant-chief-executive-indian-fil m-makers.

10. Tooke, N., \& Baker, M. (1996). Seeing is believing: The effect of film on visitor numbers to screened locations. Tourism Management, 17(2), 87-94. doi/10.1016/0261-5177(95)00111-5

11. Tourism Australia.(2012).Summary of tourism Australiaes 2020 India strategic plan. Retrieved from http:// www.tourism.australia.com/ documents/ Markets/India2020-June2012.pdf.

12. Woodside, A., \&Lysonski, S. (1989). A general model of traveller destination choice.Journal of Travel Research,27(4), 8-14. doi: $10.1177 / 004728758902700402$.

\section{AUTHORS PROFILE}

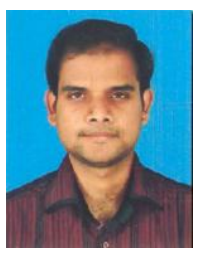

Sriganeshvarun $\mathbf{N}$ Received his Masters in Mass Communication \& Journalism from University of madras. Chennai. He is currently working as Creative director at Woodsdeck.com. He has more than 5 years teaching experience in teaching Massc Communication subjects in Chennai. He has published several research papers in UGC Journals. His area of interest are in the field of Photography, Film, Short film/ Documentary production and Tourism \& Public Relations 
Dr. Jayaprakash D is an Associate Professor \& Head at Department of Visual Communication, Meenakshi Academy of Higher Education and Research (Deemed to be University), Chennai, India. $\mathrm{He}$ has done his $\mathrm{PhD}$ from Department of Media Sciences, Anna University, Chennai, India. He has published several research papers, a book chapter and book on various aspects of Media Studies. He specializes in Digital Cultures, Film Cultures, Broadcast Media and Communication for Development. 